\title{
From Discretion to Disbelief: Recent Trends in Refugee Determinations on the Basis of Sexual Orientation in Australia and the United Kingdom
}

\author{
Jenni Millbank \\ Professor of Law, Faculty of Law, University of Technology, Sydney
}

Faculty of Law, University of Technology, Sydney, PO Box 123, Broadway NSW 2007, Australia. Email: jenni.millbank@,uts.edu.au

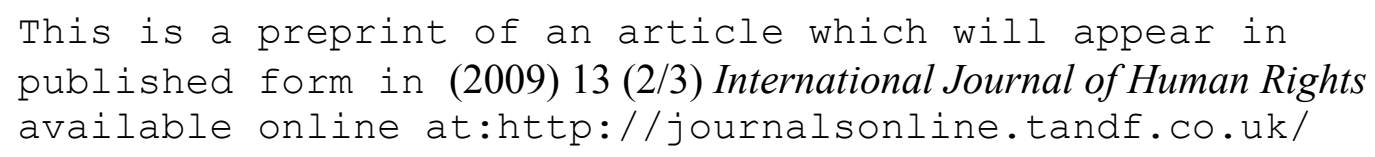

\begin{abstract}
In Appellants S395/2002 and S396/2002 v. Minister for Immigration and Multicultural Affairs, the High Court of Australia was the first ultimate appellate court to consider a claim to refugee status based upon sexual orientation. By majority the court rejected the notion prevalent in earlier cases that decision-makers could 'expect' refugee applicants to 'co-operate in their own protection' by concealing their sexuality. This paper explores the impact of S395 and S396 on the refugee jurisprudence of Australia and the United Kingdom five years on. Refugee decision-makers in both countries have been slow to fully appreciate the fact that sexual minorities are secretive about their sexuality and relationships as a result of oppressive social forces rather than by 'choice'. In addition, in Australia there has been a clear shift away from discretion towards disbelief as the major area of contest, with a significant increase in decisions where the applicant's claim to actually being gay, lesbian or bisexual is outright rejected. In an alarming number of cases tribunal members used highly stereotyped and westernised notions of 'gayness' as a template against which the applicants were judged.
\end{abstract}

\section{Introduction}

In December 2003 the High Court of Australia handed down its decision in S395 and S396, in which two Bangladeshi gay men were seeking refugee status on the ground of membership of a particular social group. ${ }^{1}$ S395 and S396 was the first decision of an ultimate appellate court anywhere in the world to deal with a claim to refugee status based on sexual orientation, and remains so to date. ${ }^{2}$ At issue was the interpretation of persecution: specifically, whether it was lawful for primary decisionmakers to consider whether gay, lesbian and bisexual asylum seekers could or should be 'discreet' (or more accurately, secretive) in their country of origin so as to avoid or lessen the risk of persecution. 'Discretion' reasoning had appeared very widely in the refugee case law of both Australia and the United Kingdom prior to that point, ${ }^{3}$ although it had been consistently rejected by lower level courts and tribunals in comparable receiving countries such as Canada and New Zealand in earlier years. ${ }^{4}$

By a narrow majority of 4 to 3 , the High Court held that the tribunal decision-maker had erred in dividing the particular social group into two subsets of 'discreet' and 'open' homosexuals and in failing to consider firstly the future-focused question of what would happen if the applicants were in fact discovered to be gay and secondly whether the need to act 'discreetly' to avoid the threat of serious harm itself constituted persecution. 5 The majority emphatically rejected the notion that decision-makers could 'expect' or had any jurisdiction to 'reasonably require' refugee applicants to 'co-operate in their own protection' by concealing their sexuality. ${ }^{6}$

This paper explores the impact of the $S 395$ and S396 decision on the refugee jurisprudence of Australia and the UK five years on through an examination of available tribunal-level determinations 
and judicial review cases concerning sexual orientation in both countries both before and after the decision. The cases analysed cover the period between 1994 and 2007, comprising 528 Australian cases (made up of 369 decisions from the Refugee Review Tribunal (hereinafter referred to as RRT) and 159 judicial review cases drawn from the Federal Court of Australia, the Federal Magistrates Court and appeals from those courts to the Full Federal Court) and 116 UK decisions (made up of 70 tribunal decisions and 46 judicial review cases drawn from the Queen's Bench and the English Court of Appeal). ${ }^{7}$

Given that our earlier research ${ }^{8}$ found a very strong correlation between 'discretion' reasoning and negative outcomes for applicants in cases from 1994 to 2003, we anticipated that disapproval of discretion-based reasoning, combined with the clear judicial summons to consider sexuality as a form of identity rather than as mere private sexual behaviour, would lead to a higher level of positive outcomes for gay, lesbian and bisexual asylum seekers from 2004 onwards. 9 Yet this has not eventuated, and in fact the overall success rates for sexual minority applicants improved little over what is now a 14-year timeframe of our study. ${ }^{10}$

We suggest that whilst S395 and S396 did have a clear positive impact on the Australian jurisprudence through the direct abolition of a highly discriminatory line of reasoning, the overall impact of the decision has been far more muted, and even arguably thwarted, by the practices of decision-makers at lower levels. ${ }^{11}$ This has been for a number of reasons. First, decision-makers in both Australia and the UK have been slow to fully absorb and apply the insight that gay people are secretive about their sexuality and relationships as a result of oppressive social forces rather than by 'choice'. A number of lower-level decision-makers have thus continued to characterise gay men and lesbians as 'naturally' discreet when possible, without actually inquiring into why this has occurred. In a related development, UK decision-makers have resisted seeing S395 and S396 as persuasive and have tended to reframe issues in terms of general UK law on persecution, thus avoiding the question of why the applicant shielded their identity from becoming known.

In addition, in Australia there has been a clear shift away from discretion towards disbelief as the major area of contest in decisions post-S395 and S396, with a significant increase in decisions where the applicant's claim to actually being gay, lesbian or bisexual is outright rejected. Our research found that in an alarming number of cases tribunal members cross-examined applicants using highly stereotyped and westernised notions of 'gayness' as a template which, when applicants did not 'fit', led to their claim of sexual identity being rejected. Moreover, both Australia and the UK have severely constricted the grounds of review available for refugee determinations in recent years, ${ }^{12}$ such that even highly dubious initial decisions are not overturned if the flaw is characterised as factual (as findings regarding applicants' motivations for secrecy, or their credibility as to membership of the group, almost invariably are).

The applicants from the $S 395$ and $S 396$ decision itself exemplified this bind: having brought a rare successful claim for judicial review to the ultimate appellate court in Australia, the men had their claim remitted to the tribunal for re-determination, expecting that it would consider whether they faced a real chance of persecution given that this was the issue in dispute at all five levels of adjudication. ${ }^{13}$ Yet on remittal the second tribunal decided that they were not gay after all, and this decision was then held to be unreviewable by the courts. ${ }^{14}$ This raises an issue of broad significance to refugee determination: the iniquity of cutting off avenues of later review without attempting to remedy the manifest flaws at earlier stages of the decision-making process. Our research also highlights the particular need to provide careful guidance and training on sexuality issues so that primary decision-makers are able to question applicants in a sensitive way and base any determination of their sexual orientation on relevant grounds.

\section{The discretion problem}

At its baldest, discretion reasoning entailed a 'reasonable expectation that persons should, to the extent that it is possible, co-operate in their own protection', ${ }^{15}$ by exercising 'self-restraint' ${ }^{\text {'16 }}$ such as avoiding any behaviour that would identify them as gay; ${ }^{17}$ never telling anyone they were gay; ${ }^{18}$ only expressing their sexuality by having anonymous sex in public places; ${ }^{19}$ pretending that their partner is 
a 'flatmate'; ${ }^{20}$ or indeed remaining celibate. ${ }^{21}$ This approach subverted the aim of the Refugees Convention - that the receiving state provides a surrogate for protection from the home state - by placing the responsibility of protection upon the applicant: it is he or she who must avoid harm. The discretion approach also varied the scope of protection afforded in relation to each of the five Convention grounds by, for example, protecting the right to be 'openly' religious but not to be openly gay or in an identifiable same-sex relationship. ${ }^{22}$

The appearance of discretion reasoning in a decision strongly correlated to failure for lesbian and gay applicants. In Australia from 1994 to 2003 discretion appeared as an issue in the text of 114 of the tribunal decisions, representing almost 40 per cent of publicly available RRT cases on sexual orientation through that period. When discretion appeared as an issue, applicants had a failure rate of 70 per cent at tribunal level, a figure roughly in line with failure rates for sexual orientation claims in Australia overall. ${ }^{23}$ However, where it was clear from the reasoning that discretion was identified as something that was a 'reasonable' expectation or requirement of the applicant, the failure rate rose to 98 per cent at tribunal level. ${ }^{24}$ In the UK, discretion was raised almost as often as in Australia, appearing as a consideration in 34 per cent of tribunal-level cases. ${ }^{25}$ The impact was even more significant: when discretion was raised at all, applicants had a failure rate of 90 per cent at tribunal level, and this rose to 100 per cent when it was apparent from the reasoning that discretion was an expectation. ${ }^{26}$

The role of discretion in the Australian and UK cases has been extensively critiqued elsewhere, ${ }^{27}$ so only a few brief comments will be made here on how it was manifested and the errors of reasoning that it led to. The idea of discretion reflects broader social norms concerning the 'proper place' of lesbian and gay sexuality, ${ }^{28}$ as something to be hidden and reluctantly tolerated, a purely private sexual behaviour rather than an important and integral aspect of identity, or as an apparent relationship status. The discretion approach explicitly posited the principle that human rights protection available to sexual orientation was limited to private consensual sex and did not extend to any other manifestation of sexual identity ${ }^{29}$ (which has been variously characterised as 'flaunting',30 'displaying'31 and 'advertising'32 homosexuality as well as 'inviting'33 persecution). Thus for example in 2001 the Federal Court of Australia held that the Iranian Penal Code prohibiting homosexuality and imposing a death penalty did 'place limits' on the applicant's behaviour; the applicant had to 'avoid overt and public, or publicly provocative, homosexual activity. But having to accept those limits did not amount to persecution.'34 On appeal, the Full Federal Court endorsed the view that 'public manifestation of homosexuality is not an essential part of being homosexual'. 35 The discretion approach thus has had wide-reaching ramifications in terms of framing the human rights of lesbians and gay men to family life, freedom of association and freedom of expression as necessarily lesser in scope than those held by heterosexual people..$^{6}$

Discretion reasoning also led to and compounded errors in a range of areas of analysis in the refugee determination process, including the role of internal relocation alternatives, the likelihood of objective risk based on country evidence, and the relationship between the criminalisation of gay and lesbian sex to the unavailability of state protection. Each of these issues will be briefly outlined below.

In making a determination of the likelihood of persecution, decision-makers may consider whether the applicant would be safe elsewhere in his or her country, either because there is a lesser chance of persecution occurring if the threat of harm is itself localised, or because there is greater sufficiency of state protection in some areas. ${ }^{37}$ In considering internal relocation, decision-makers also take into account questions of 'reasonableness', considering the individual impact on the applicant of relocation, including whether doing so would isolate them from sources of financial and emotional support..$^{8}$ In sexuality cases, internal relocation considerations typically involve asking whether the applicant could move from a rural or remote area where they have been endangered to a larger metropolitan setting, 39 often the capital city - not uncommonly characterised as having a 'thriving' gay scene - often by reference to listings of social venues drawn exclusively from tourist guides. ${ }^{40}$ Discretion reasoning clouded the consideration of internal relocation by implicitly or explicitly assuming that the purpose of relocation was to achieve (re)concealment rather than to move to a place of actual safety and sufficiency of state protection. ${ }^{41}$ This was glaringly illustrated by the following exchange drawn from the transcript of an RRT hearing in 2002 in which internal relocation was held to be reasonable: 


\begin{abstract}
Applicant: $\quad$ I tried to approach the police...
Member: Well you don't need to approach the police now... you know that that's useless, your aim now is to stay away from gay bashers ... and abm prying family neighbours ... there must be more anonymous accommodation. 42
\end{abstract}

In short, discretion reasoning led to the assumption that applicants would be safe in a big city because no-one would know they are gay (and they can keep it that way), rather than because it actually was safe to be gay in a big city.

Discretion reasoning also led to misreading and misrepresentation of general country information on the objective risk of persecution for members of the group. Because this line of reasoning assumed that applicants should and would conform to their culture or government's oppressive regimes in order to avoid harm, decision-makers avoided assessing the magnitude of the harm posed, including harm as serious as the death penalty, 43 and balancing that harm in the assessment of risk. In the Australian tribunal decisions, the assumption of discretion was held to foreclose the question of risk to the extent that on occasion there was literally no assessment at all of the country situation and the risk of harm to someone who was identified as gay or lesbian. ${ }^{44}$ It also led to some wildly improbable conclusions on country conditions, most notably that Iran was 'tolerant' of homosexuality. ${ }^{45}$

In both Australia and the UK it was notable that discretion reasoning compounded longstanding errors in examining the role of criminal law when assessing likelihood of persecution. Decisionmakers routinely dismissed criminal proscriptions on gay and lesbian sex as 'theoretical' and not persecutory if there was insufficient evidence that they were regularly enforced. ${ }^{46}$ Embedded in the finding of non-enforcement was the assumption that applicants would not - and could not - alert authorities to their sexuality, thus overlooking the crucial question of what kind of state protection would be available if members of the group experienced sexuality-based violence and police were to characterise them as criminal offenders rather than victims. (Indeed in some cases judges and tribunal members have actually referred to the applicant as a 'potential offender' 47 and to gay sex as 'sexual misconduct'.48) Thus discretion reasoning obscured the important connection between formal criminal sanctions, whether or not regularly enforced, and the failure of state protection from harm caused by both state and non-state actors.

In sum, discretion reasoning detracted from the future-focused nature of the well-founded fear test: in effect making it virtually impossible for a claim to succeed unless an applicant could demonstrate past persecution through their sexuality already becoming known in their country of origin. 49

\title{
The end of discretion as we knew It
}

The High Court decision in S395 and S396 should have provided a remedy to the numerous flaws of reasoning outlined above. The two majority judgments expressly found that refugee decision-makers could neither assume nor require discretion and held that the assessment of persecution must inquire into both why the applicant concealed their identity and what would occur if it were revealed as part of the process of identifying whether there was a well-founded fear. ${ }^{50}$

Australian case law from 2004 onwards does demonstrate a positive impact from the judgment. In the 2004-2007 period, discretion was raised in 52 cases in Australia, representing 30 per cent of publicly available refugee decisions on sexual orientation. Almost half of these were judicial review decisions, reflecting both an overall rise in the number of judicial review applications in these later years in the pool of Australian cases and the likelihood that the $S 395$ and $\$ 396$ decision itself precipitated a number of applications for review. ${ }^{1}$ At tribunal level when discretion was raised as an issue in the post-S395 and $S 396$ period of 2004-2007, the failure rate dropped to 27 per cent — almost a mirror reversal of the pre-S395 and $S 396$ success and failure rates when the issue of discretion appeared.52 Tribunal decision-makers now commonly accept applicants' claims that they would rather be open about their sexuality (rather than querying the 'reasonableness' or 'right' to do so). So, for example, we see statements from 2004 onwards such as: 
I accept that his situation has changed from that in Bangladesh in that he is now openly gay and he can not hide his sexual feelings now he has lived this lifestyle in Australia. I accept that it would be different for the applicant if he were to return to Bangladesh now. The applicant fears that he would have to hide his true identity and that he would suffer repercussions when his sexuality was revealed.53

In a number of recent cases the tribunal also held that concealment of one's sexuality was or would be persecutory. 54

There was only a small number of UK cases available in the 2004-2007 period, probably due to the restriction from April 2005 of tribunal review to points of law only.55 Yet of the handful of available cases, most did address the issue of discretion and these had a markedly low failure rate compared to the earlier period. Of a total of 16 tribunal cases, 12 raised the issue of discretion - 6 of which were positive decisions. ${ }^{6}$ Although it may be hard to generalise from such a small number of cases, it is still striking that, as in the Australian cases, this represented almost a mirror reversal of success/failure rates from the pre-S395 and $\$ 396$ era.

It now appears far more likely that decision-makers in sexual orientation cases in both Australia and the UK properly address the risk of persecution question by weighing the likelihood of exposure to persecutors with the severity of harm posed, rather than simply assuming that the threat, however severe, can be avoided by secrecy.

In addition, the High Court of Australia by majority held in S395 and S396 that living in a state of fearful concealment could itself be found to be so oppressive as to constitute persecution. Justice McHugh and Justice Kirby stated:

In cases where the applicant has modified his or her conduct, there is a natural tendency for the tribunal of fact to reason that, because the applicant has not been persecuted in the past, he or she will not be persecuted in the future. The fallacy underlying this approach is the assumption that the conduct of the applicant is uninfluenced by the conduct of the persecutor and that the relevant persecutory conduct is the harm that will be inflicted. In many - perhaps the majority of - cases, however, the applicant has acted in the way that he or she did only because of the threat of harm. In such cases, the well-founded fear of persecution held by the applicant is the fear that, unless that person acts to avoid the harmful conduct, he or she will suffer harm. It is the threat of serious harm with its menacing implications that constitutes the persecutory conduct. 57

They concluded that to 'determine the issue of real chance without determining whether the modified conduct was influenced by the threat of harm is to fail to consider that issue properly'. ${ }^{8}$ It is this latter aspect of the judgment that has been less successfully translated into practice in lower-level decision-making, as decision-makers have continued to avoid asking the question: why has the applicant lived in secrecy?

\section{Avoiding and undermining S395 and S396- No need to inquire into the naturally discreet}

A guide to the path that decision-makers would take to avoid fully addressing the implications of S395 and $\$ 396$ was provided by the dissenting judgments in that case. In particular the joint dissenting opinion of Justice Callinan and Justice Heydon reinscribed discretion as a 'naturally' occurring state for the applicants specifically and also as a neutral state of social grace that encompassed all people generally without discrimination, including heterosexual people. 59 The dissenting judges placed a clear onus on applicants to bring a claim at first instance demonstrating that their lives of former secrecy were motivated largely — or even solely — through fear of harm. ${ }^{60}$ The absence of such proof was taken as demonstrating that a life of secrecy is a matter of 'free choice':

The question in this case was not, as the appellants contended, whether, absent imposed or enforced discretion as to their homosexuality, they would be likely to be 
persecuted in their country of origin, but whether their mode of conduct was voluntarily chosen, and had and would not provoke persecution of them. ${ }^{61}$

Justice Callinan and Justice Heydon found that the appellants 'were not oppressed'62 as they were discreet as a matter of 'free choice'. ${ }^{63}$ In cases decided since then, tribunal members in both Australia and the UK have held for example that a closeted lesbian relationship 'does not seem to us to be so very different from the conventional married lives of many other couples who neither flaunt their sexuality nor adopt an overtly heterosexual lifestyle'; 64 that 'the sexual practices and behaviour of all people, whether heterosexual or homosexual are not matters that are made public';65 and that 'discretion in their public sexual practices ... [is] part of the ordinary consensus of civilised mankind'. ${ }^{66}$ These remarks indicate a profound and continuing failure to comprehend the hegemonic and naturalised expression of heterosexuality in all cultures. Such a frame of reference renders it possible to avoid the implications of $S 395$ and S396 by (re)constructing the applicant's fear as an individualised preference or as an expression of their 'natural' personality or character. ${ }^{67}$

The combined effect of these assumptions is to place a heavy onus on applicants to raise the issue of suppression at first instance. ${ }^{68} \mathrm{~A}$ number of recent judicial review decisions in the UK have held that it is the applicant who must raise, and prove, that their life of 'discretion' was largely or solely in response to fear of persecution; the decision-maker has no duty to inquire. ${ }^{69}$ In the 2005 UK case of $R G$ the court went so far as to find that the applicant had to raise and prove the persecutory nature of suppression as a distinct issue in addition to his fear of persecution generally. Evidence was submitted at first instance by a doctor who stated that:

If [the applicant] is returned to Colombia, it is likely to be highly traumatic for him. Firstly, he would have to immediately try to repress his sexuality and live a double life, living as if he is not homosexual (when I asked him how he would be affected by this, he said: 'For me, it would be to die.') Suppression of his sexual identity is likely to have traumatic effects. ${ }^{70}$

The original adjudicator ignored this report in holding that the applicant would 'regulate his behaviour' to avoid 'unwelcome attention' which would place him in 'danger', ${ }^{71}$ such that with 'one or two elementary precautions ${ }^{72}$ he would not be at risk as an HIV-positive gay man in Colombia. Yet on judicial review the English Court of Appeal accepted the Home Secretary's argument that there was no error because:

it was RG's case throughout that what he feared was the actual persecution of the death squads, not the consequence to his psychology of trying to avoid them. ${ }^{73}$

It is also notable that UK decision-makers were openly reluctant to see S395 and S396 as persuasive authority or as contributing something 'new' to its own refugee jurisprudence. English decisionmakers responded that S395 and S396 was not novel because the majority judgment of Justice McHugh and Justice Kirby had cited an English Court of Appeal decision on political persecution ${ }^{74}$ in support of the principle that an applicant was not required to avoid persecution by modifying behaviour if such modification would itself be persecutory. ${ }^{75}$ In doing so, English courts either missed or deliberately misread the crucial point that persecution principles had been very differently applied in cases concerning sexuality in contrast to cases on political grounds in both countries prior to S395 and S396. Thus the UK tribunals and courts considering S395 and S396 reordered it into their own frame of reference and excluded the most challenging aspect of the decision which was that, in order to properly address the issue of persecution, there is a duty to inquire why applicants have concealed their sexuality.

Using older English cases as the frame of reference allowed an easy slippage back into assumptions of 'natural' discretion informed by stereotyped ideas of sexual identity as a concealable form of sexual behaviour only acceptable in its 'proper place'. This is borne out by the striking fact that the one English case to fully engage with the ideas raised by S395 and S396, and to imaginatively and empathically consider the real day-to-day impact of a life of secrecy, did not actually concern a gay applicant or a same-sex relationship. In $H Y S I^{6}$ the applicant was a man from Kosovo of mixed Albanian and Roma ancestry who claimed that once his mother's Roma ancestry was known he 
would be subject to persecution. At first instance the adjudicator held, in an echo of many of claims based on sexual orientation, that the applicant could internally relocate in order to conceal his identity and thus live a 'normal' life. The English Court of Appeal in addressing the question of whether this would be 'unduly harsh' in the context of relocation jurisprudence considered that:

this would probably involve the appellant leading a hermit-like existence, indeed without any social intercourse based on trust. As a stranger he is bound to be asked questions. He would presumably have to lie. Even if he could provide some colourable but some untruthful explanation for his arrival in the new location ... he would have to live with that lie. ... Moreover, he would thereafter have to avoid letting slip any intimation of his true ethnicity, or his constant lies. He would simply have to continue to lie and conceal his origins, while simultaneously living with the risk that the truth would be suspected or discovered...

More significantly, however, this consideration serves to highlight that continuing deliberate concealment of his identity on relocation carries with it the unavoidable conclusion that this particular son should ignore his mother. ${ }^{77}$

This detailed and textured engagement with what it would actually mean to the applicant's sense of self-identity, encompassing both social interaction and the ability to claim a familial relationship, stands in stark contrast to the approach of the UK Tribunal in a number of recent cases concerning sexual orientation. The blithe assurance of the tribunal in $A T$ in 2005 that a life of secrecy, fear and shame for lesbian and gay people is simply part of the 'ordinary consensus of civilised mankind'78 may have been tempered in expression in later cases, but the approach it rests upon has continued. In the 2008 case of $J M$ the Tribunal characterised the secrecy of a gay man in Uganda as him 'being mindful of his society's concepts of good manners and the general social mores.79 At the risk of belabouring the point, it is hard to imagine the Tribunal characterising, for example, the inability to freely express one's political opinion as good manners.

Disturbingly, in the 2008 case of $H J$ concerning a gay man from Iran, the Home Secretary put forward the circular argument that an applicant having had a past life of secrecy in their home country was in itself proof that a life of secrecy is a tolerable state, claiming that:

self-restraint due to fear will be persecution only if it is such that a homosexual person cannot reasonably be expected to tolerate such self-restraint. Where a person does in fact live discreetly to avoid coming to the attention of the authorities he is reasonably tolerating that position. ${ }^{80}$

This argument was largely accepted by the tribunal which noted that, 'Homosexuals may wish to, but cannot, live openly in Iran as is the case in many countries' 81 and held that 'To live a private life discreetly will not cause significant detriment to his right to respect for private life, nor will it involve suppression of many aspects of his sexual identity. ${ }^{\prime} 2$ In $H J$ and $J M$ it appears that the shift in law from asking whether the applicant 'should' be secretive to asking whether he can 'reasonably be expected to tolerate' secrecy has not materially altered the Tribunal's approach to the interpretation of persecution. ${ }^{83}$

\section{Sexual identity as 'an allegation ... easy to make and impossible to disprove' $\mathbf{8 4}$}

The real mischief ... that is likely to be caused by this allowing his appeal is by encouraging a flood of fraudulent Zimbabwean (and no doubt other) asylumseekers posing as sodomites. ${ }^{85}$

Credibility is very often an issue of significance in refugee determinations; indeed it is common for some or many aspects of a claim to be disbelieved, even in claims that are ultimately successful. In determinations on the basis of sexuality there will rarely be any 'objective' or external markers of the claimant's membership of the group in the way that there will more often be for other grounds such as political opinion. In particular, if the claimant was not open about his or her identity before leaving the country of origin, evidence of membership will largely consist of the claimant's own account of his or her feelings and experiences. 
In our study we did not find evidence that $S 395$ and $\$ 396$ led to an influx of fraudulent claims. ${ }^{86}$ What we did find, however, was a significant increase in the proportion of Australian decisions where the applicant's claim of a gay, lesbian or bisexual identity was specifically doubted or disbelieved, from 16 per cent of available cases prior to $S 395$ and S396 to 38 per cent of cases in the 2004-2007 period. ${ }^{87}$ We suggest that there has been a shift in this period from 'discretion' to 'identity disbelief as the major ground for negative determinations in Australia. It is possible that decision-makers relying upon 'discretion' reasoning to find no risk of persecution felt relieved of the task of making a searching examination of applicant's identity claims, leading to a far greater emphasis on testing identity in the post-S395 and $S 396$ period. The small number of available UK tribunal decisions available during this time, combined with the confinement of tribunal review to points of law, renders it impossible to determine if a similar trend has occurred in that jurisdiction; therefore the following discussion addresses exclusively the Australian cases.

The wide scope for variable determinations as to credibility about membership of the group is exposed in a particularly glaring fashion when cases are returned to the tribunal for redetermination following a successful application for judicial review; most notably in S395 and S396 itself. As the Australian tribunal has complete access to, but is not bound by, earlier findings on remittal it is free to make a completely inconsistent (and unreviewable) finding of fact. In the two original delegates' decisions and in the first joint tribunal decision, the two Bangladeshi men in 5395 and 5396 were believed on some aspects of their claim of past persecution and disbelieved regarding several other aspects, but were accepted at both stages as being truthful in their claims to be gay and in a long-term relationship with each other. Having brought two unsuccessful applications for judicial review and finally succeeding before the High Court, their applications for refugee status were returned to the tribunal for rehearing in 2005. The tribunal then held, some 6 years after their first claims in which they had consistently presented and been accepted as a gay couple, that they were not actually gay. ${ }^{88}$ In a similar matter the Federal Magistrates Court refused review of a tribunal's belated decision that the claimant was not gay, stating that '[s]exual orientation is essentially a very subjective matter. It is not easily reconciled with the notion of objective proof. ${ }^{89}$ Whilst the cases were replete with references to 'allegations' of gay identity as something that were easy to make and hard to disprove 90 (in an uncanny echo of the rape mythology that women have faced in the legal system for centuries ${ }^{91}$ ) it could just as readily be argued based on our research that findings of the falsity of sexual identity in refugee determinations are easy to make and impossible to appeal.

Whilst not suggesting that every claimant who brings a claim based on sexual orientation is truthful, ${ }^{92}$ this section of the paper argues that the Australian cases on identity and credibility evince some extremely disturbing trends, not least of all because inquiry into such issues appears to have proceeded without any kind of formal training into culturally appropriate or sensitive methods of eliciting information on the complex and personal questions of sexual identity and experience. As one RRT decision noted, in a rare articulation of anything other than the 'ease' of false claims, it is

difficult for applicants to substantiate and for decision-makers to evaluate [claims on sexual orientation]. By their very nature, they involve private issues of selfidentity and sexual conduct, and sometimes personal issues for individuals that may be stressful or unresolved. Social, cultural and religious attitudes to homosexuality in an applicant's society may exacerbate such problems. ${ }^{93}$

Yet in numerous cases it appears from the text of decisions that applicants were questioned principally about matters such as the locations and names of gay nightclubs in Sydney and Melbourne to assess their familiarity with the gay 'scene'. Nicole LaViolette has noted that the experience and understanding of one's sexual orientation can vary enormously, 'depending upon their country of origin, gender, culture, social class, education, religion, family background, and socialization. There is no uniform way in which lesbians and gay men recognize and act on their sexual orientation.'94

Surely it is an unreasonable expectation of individuals from elsewhere in the world who are attracted to members of the same sex that they should be interested in and attend gay bars and clubs in innercity locations in Australia as a matter of course upon their relocation here, yet when applicants responded that they were not familiar with the locations of gay bars, asserted a preference for 
socialising privately or in other venues or suburbs, or claimed to have gone to mainstream pornography venues for male-male sex, they were disbelieved.95 (Moreover when applicants did name bars they had attended, some tribunal members took steps such as telephoning the named bars to ask whether the staff remembered them. ${ }^{96}$ )

In a 2005 tribunal case, a bisexual applicant stated that he had been to a gay sauna and gave an accurate description of its location although he was unable to name it. The tribunal member then peppered the applicant with detailed questions about this sex-on-premises venue, addressing the applicant's experience and recollection of the changing room because, in the tribunal's words, 'what happens after that is potentially sensitive and individual'97 (although it appears that the tribunal member did in fact ask repeatedly about what occurred 'after your shower'98). Whilst the gist of the applicant's claim was that his companion had paid money and received something in return at the entrance, and that the locker-room was dark, the tribunal used a website photo of the venue to decide that the venue could not have been dark and held that it did not 'make sense that patrons would be handed a ticket in a place where people commonly wear only towels and get wet.'99 On judicial review, the transcript revealed that it was in fact the tribunal member himself who had introduced the idea of a ticket in his questions, the applicant never having mentioned it; yet the decision was not disturbed by the court. ${ }^{100}$

There are numerous other indications that Australian decision-makers are continuing to apply stereotyped ideas of what it means to be gay, or preconceptions as to what a gay identity necessarily entails. For example, in some cases where the applicants indicated (whether or not as part of their claim) that they adhere to a religious faith the tribunal held that this impugned their claim to be gay or lesbian. ${ }^{101}$ In a 2003 decision the tribunal stated:

Having regard to the teachings of the Catholic Church I am firmly of the view that a person of single sex orientation must have at least considered their position in the Church and whether they wished to continue to practise ... Catholicism. ${ }^{102}$

Most unusually this case was overturned in a judicial review decision in which the Federal Magistrates Court not only applied but extended the reach of $\$ 395$ and S396, citing it for the proposition that it may be jurisdictional error to expect an applicant to behave in a particular way' and finding that the RRT 'erred by expecting the applicant, if he were truthful, to behave like a "good" Catholic'. ${ }^{103}$

In other cases, tribunal members held that applicants could not be gay because they did not know the legal status of gay sex in their countries of origin, ${ }^{104}$ did not know the meaning of words used to identify (very particular kinds of) gay men, ${ }^{105}$ or appeared from their 'manner towards each other' to be more like friends than lovers. ${ }^{106}$ There were also instances in which applicants' unwillingness, or inability, to answer detailed questions about sexual acts or encounters was held to undermine their credibility. ${ }^{107}$

In a 2001 case the tribunal member repeatedly asked the applicant, who was from Iran, about his identification with popular culture in order to determine if he was gay.

Mr Hardy: Well I put it to you that this isn't something that you can switch on and off [a reference to the applicant's homosexuality], it's something that, particularly if it isolates you, it can take over your whole life. It can be the lens through which you see the whole world, if you're lonely enough as a result of, or feel isolated enough as a result of being different from other people ... um here, sorry bere's an example. Here's an example. If, if say, a famous Egyptian novelist wins the Nobel Prize, but he's also a homosexual who writes about, ah, you know, the love between two men. It mightn't be a big part of his story but it might be an element in the novel, right. Just say be gets banned in Iran, okay. Might not your ears prick up when you bear that that author bas been banned in Iran, and you go, oh, yeah, that's another, that's just another case, just another problem.

The applicant: I don't understand it. I'm sorry. ${ }^{108}$ 
In a passage which needs to be quoted at length to be fully appreciated, the tribunal member listed a series of examples of cultural 'phenomena' and 'icons' that might indicate homosexual orientation:

The Tribunal asked the Applicant which, if any, art, literature, song lyrics or popular culture icons spoke to him in his isolation from the rest of the society. The Applicant provided not one example. He said he did not understand the question. The Tribunal asked him if his ears pricked, say, when he heard of any famous, perhaps foreign artist, performer or author being banned in Iran for reasons of immorality. In reply, he said he did not understand the question. The Tribunal was not demanding that the Applicant be a leading Gide scholar or even a Marilyn Monroe fan, but it did seem odd that the sexuality he was forced to suppress in Iran did not find expression in any phenomena at all, whether in high culture or low, also considering that he claimed elsewhere to have been alert to what was happening in countries like Australia...

The Tribunal thus well understands that it should not expect all or any homosexual men in Iran to take an interest, for example, in Oscar Wilde, or in Alexander the Great, or in Naguib Mahfooz, or in Greco-Roman wrestling, or in the songs of Egypt's tragic muse Oum Khalsoum, let alone, say, in the alleged mystique of Bette Midler or Madonna. ... However, the Tribunal was surprised to observe a comprehensive inability on the Applicant's part to identify any kind of emotionstirring or dignity-arousing phenomena in the world around him. ${ }^{109}$

Whilst overtly disclaiming that manifesting an interest in Oscar Wilde et al. was required of an applicant who claimed to be gay, the kind of questioning evinced in the case - which apparently went on to address the applicant's familiarity with the work of Freud (deemed 'negligible'110) together with the tone of the decision appears to suggest just the opposite. Unusually, the applicant was successful in his application for judicial review on the very difficult ground of actual bias, as the Federal Magistrates Court held that the questions revealed 'a pre-formed template into which the Tribunal considered all homosexual males would fit' and a 'completely closed' approach to the issue. ${ }^{111}$ The Minister then appealed to the Full Federal Court which reinstated the tribunal decision and held that it was a 'matter of common sense' and 'perfectly legitimate' to test a claim 'by reference to knowledge or attitudes which manners of the relevant religion, social group or political party might be expected to posses'. ${ }^{112}$ If the applicant were Catholic, the Full Court reasoned, 'the RRT might test this assertion by enquiring as to the applicant's knowledge of matters of Catholic doctrine, ritual, traditional belief and the like'. ${ }^{113}$ Whilst the Full Court appeared blind to the critical absence of a universally known or accepted doctrine (or even standard King James edition) on gay cultural icons, the applicant was eventually granted leave to appeal to the High Court two years later.

The transcript of the leave to appeal hearing reveals that the three sitting High Court members were far less sanguine than the Federal Court had been about the tribunal's manner of establishing that the applicant was gay. Justice Gummow noted that the applicant had only a secondary school level of education and spoke Farsi such that 'one would doubt if he knew anything about famous Egyptian novelists' who 'write in Arabic, presumably', ${ }^{114}$ whilst Justice Kirby repeatedly raised the question of stereotyping ${ }^{115}$ and Justice Heydon characterised the tribunal decision as giving the impression of nonchalance' and 'a certain amount of sneering'. ${ }^{116}$ When counsel for the Minster clung to the argument that the tribunal had claimed it did not expect the applicant to take an interest in the named 'icons', Justice Kirby retorted that 'the "not" is a bit undone by what follows when I think Marilyn is thrown in'. ${ }^{117}$ Justice Gummow was even more critical of the use of disclaimers in the decision:

Gummow: What sort of training do these people get in decision making before they are appointed to this body, Mr Solicitor?

Mr Bennett: I cannot assist your Honour on that.

Gummow: No. Well, whatever it is, what happened here does not speak bighly of the results of $i^{118}$ 
Given the tone of these remarks it was not surprising that the Minister consented to remit the matter back to the tribunal prior to the substantive determination of the appeal by the High Court. ${ }^{119}$ Unfortunately, however, the remittal by consent ensured the continued absence of a clear judicial overruling of the Full Federal Court's decision in $W A A G$ which had expressly validated this kind of 'gay-catechism' approach to sexual identity. The Full Federal Court's decision in $W A A G$ clearly discouraged judicial review of other ill-founded or illogical tribunal determinations that the applicants were not gay, lesbian or bisexual. ${ }^{120}$ It also bodes ill for the system of refugee determination that a decision as plainly troubling as this could be repeatedly defended by the Minister (including initiating an appeal from the Magistrate's judgment which had set it aside) and moreover be upheld by three out of four judges adjudicating it before it was finally set aside by consent some four years after it had been made. ${ }^{121}$

Accepting that the tribunal does validly need to assess the credibility of applicants' claims to be gay, lesbian or bisexual, some suggestions are made in the next section as to how this can be undertaken.

\section{The need for training and guidelines}

There is now a considerable body of refugee scholarship which poses credibility assessment as the most critical aspect of the refugee determination process and contends that it is often undertaken inappropriately. ${ }^{122}$ Whilst some researchers have emphasised the use of guidelines to structure the decision-maker's approach to the task, ${ }^{123}$ many others have argued that transforming institutional culture through avenues such as on-going training are more important in creating a place for 'critical reflection'124 in the assessment of truth-telling.

When sexual orientation claims first emerged in Canada in the early 1990s, tribunal members themselves requested training on the issue as they did not feel equipped to judge whether or not the applicants were members of this particular social group. ${ }^{125}$ Nationwide sexual orientation training was first provided to the Canadian tribunal as long ago as 1995 by an external expert, Nicole LaViolette, and has been regularly updated since then. ${ }^{126}$ In addition, the 2003 compendium to the Canadian Gender Guidelines does address, albeit in a limited way, sexual orientation. ${ }^{127}$

LaViolette argues that, the 'one aspect of the lives of lesbians and gay men that is universal is the pervasive societal rejection of their sexual orientation ... most lesbians and gay men will struggle with their sexual identity at some point in their lives'. ${ }^{28}$ Thus, she contends that questions about the personal experience of being gay or lesbian provides the 'strongest basis' for assessing credibility as to group membership. This is not the same, however, as questioning applicants about their sexual activities. Unlike those making claims based on other Convention grounds, applicants who seek refugee status on the basis of sexual orientation often have feelings of shame and self-hating or internalised homophobia ${ }^{129}$ and so may find answering questions about their sexuality very difficult, most especially when these questions are sexually explicit and/or when they are being questioned by an authority figure. ${ }^{130}$ Additionally, if the translator is a member of the same small community in the receiving country and/or is a member of the opposite sex, the applicant's willingness to make disclosures can be seriously compromised. ${ }^{131}$ All of these constraints must be taken into account in the process of eliciting information and in assessing narratives that vary in particulars or are not initially detailed.

LaViolette's Canadian training materials suggest three areas of inquiry, being (i) Personal and Family, (ii) Lesbian and Gay Contacts in both sending and receiving country, and (iii) Experience/Knowledge of Discrimination and Persecution. Most importantly for our purposes, in this first field, LaViolette suggests a series of open-ended questions that invite the applicant to tell their narratives of how they came to their own self-knowledge or experience of 'difference', how they felt about it and how others reacted, without resorting to intrusive questions about sexual experiences.

In March 2008, the Australian tribunal finally conducted a single external training session for two hours on sexual orientation issues. ${ }^{132}$ This training was undertaken as the result of a federal Senator highlighting the case of a bisexual-identified claimant from Pakistan. ${ }^{133}$ Ali Humayan was in a longterm same-sex relationship which had begun during immigration detention yet he was held by the 
tribunal to be neither gay nor bisexual but rather the 'product of the situation where only partners of the same sex are available'. ${ }^{134}$ The case generated intense media interest and significant public criticism. ${ }^{135}$ Given this context it is unclear what degree of commitment there is to on-going training (either in the induction process for new members or update training for existing members) or to incorporating external input on sexual orientation issues in a systematic way through all levels of the refugee determination process.

There are also no internal or external guidelines available to assist decision-makers in sexual orientation cases in Australia at either tribunal or original Minister's delegate level. ${ }^{136}$ The Australian gender guidelines, introduced in 1996 and not revised since, ${ }^{137}$ do not include any reference to sexual orientation. Whilst the UK tribunal-level gender guidelines introduced in $2000^{138}$ did make numerous references to sexual orientation, including as an integral aspect of gender norms, when the tribunal was abolished and reconstituted in 2005 the new tribunal determined that it was not bound by its predecessor's guidelines. ${ }^{139} \mathrm{New}$ gender guidelines brought in by the Home Office in the UK (first issued in 2004 and revised in 2006) to guide determinations at the bureaucratic level are far less comprehensive and do not contain specific material on sexual orientation. ${ }^{140}$ In addition, in both Australia and the UK there is evidence that the relevant gender guidelines, however incomplete in their coverage, have been honoured more in the breach than the observance at all levels of the refugee determination process ${ }^{141}$ and moreover have been completely ignored in sexual orientation cases. ${ }^{142}$ In both countries community groups have begun actively lobbying to generate specific sexual orientation guidelines. ${ }^{143}$ UNHCR has recently released a guidance note on the determination of sexual orientation claims which addresses many of the issues raised here. ${ }^{144}$ The research outlined in this paper suggests that in addition to the creation of detailed guidelines, comprehensive and ongoing training about their use is also needed.

Bearing in mind the extremely restrictive grounds of review for refugee decisions, the importance of high quality, consistent and factually well-founded decisions at the merits stage is fundamental if the refugee determination system is to sustain any claim to fairness. Failure to address these concerns will ultimately undermine any real gain from S395 and S396.

\section{Conclusion}

The rejection of 'discretion' reasoning by the High Court in S395 and S396 was a critical juncture for refugee law in Australia and the UK, marking a definitive break from earlier decisions which had implicitly or explicitly framed the entitlements of refugee claimants on the basis of sexual orientation as lesser than those brought by others. In doing so, S395 and S396 established the right of refugee claimants to be openly gay, lesbian or bisexual and has improved the likelihood of successful claims based on sexual orientation. The determination also brings refugee jurisprudence in these two countries more closely in line with developments in international human rights jurisprudence, which has expanded in recent years to encompass a far more substantive approach to equality and to private life. ${ }^{145}$

However, the promise of this development has also been undermined, particularly at lower (which are also, increasingly, the final) levels of factual decision-making in the refugee determination process. Our research found a reluctance to fully engage with and implement the findings of $S 395$ and S396 through on-going assumptions about the 'naturalness' of secrecy about gay, lesbian or bisexual identity and consequent failure to inquire into the oppressive social and legal conditions that create and perpetuate such secrecy. In addition, we found a distinct shift in the Australian decisions towards outright disbelief in claimants' identity as a major basis for negative determinations. Here again, deeply held assumptions about how gay, lesbian or bisexual identity are, or ought to be, manifested have played a significant role in determining outcomes. In a disturbing number of cases, a finding that the applicant was not a member of the particular social group appeared to result from quite dubious or improper questioning, and indeed on occasion reflect outright stereotyping in the decision-making process.

These recent trends in sexual orientation refugee case law highlight the broader and on-going need for improved resources earlier in the refugee determination process, as well as the necessity for a return to the greater availability of judicial oversight in order to correct errors when they do occur. 
The introduction and maintenance of expert external training on sexuality issues and the creation and implementation of guidelines on sexual orientation may not be the answer to every criticism identified in this paper, but they will help to ensure that early level determinations on sexual orientation claims are both more consistent and more reliable.

\section{Acknowledgements}

This study was devised in conjunction with Professor Catherine Dauvergne at the University of British Columbia and I am enormously grateful for her input at every stage of the project. This research was supported by an Australian Research Council Discovery Project Grant. Thanks to Laurie Berg, Katherine Fallah, and Marianna Leishman for their invaluable research assistance.

\section{Notes}

1 Appellants S395/2002 and S396/2002 v. Minister for Immigration and Multicultural Affairs (2003) 216 CLR 473 (hereinafter referred to as ' $S 395$ and $S 396$ ').

${ }^{2}$ Article 1A(2) of the 1951 Convention Relating to the Status of Refugees, 189 UNTS 150, as amended by the 1967 Protocol Relating to the Status of Refugees, 606 UNTS 267 (hereinafter referred to as Convention) defines a refugee as any person who 'owing to well-founded fear of being persecuted for reasons of race, religion, nationality, membership of a particular social group or political opinion, is outside the country of his nationality and is unable or, owing to such fear, is unwilling to avail himself of the protection of that country; or who, not having a nationality and being outside the country of his former habitual residence, is unable or, owing to such fear, is unwilling to return to it'. Sexual orientation was accepted as the basis for a particular social group claim in most major refugee receiving nations by the mid-1990s: see, e.g., Re R (UW) [1991] CRDD No 501 (Quicklaw), IRB Reference U91-03331 (7 October 1991); Ward v. Attorney-General (Canada) [1993] 2 SCR 689 (Canada); Matter of Toboso-Alfonso, 20 I\&N Dec 819 (BIA 1990) (USA); N93/00593 [1994] RRTA 108 (25 January 1994) (Australia); Applicant A v. Minister for Immigration and Ethnic Affairs (1997) 190 CLR 225 (Australia); V raciu v. Secretary of State for the Home Department [1994] UKIAT 11559 (21 November 1994); R v. Immigration Appeal Tribunal, ex parte Shah [1999] 2 AC 629 (HL) (United Kingdom).

${ }^{3}$ See discussion in Catherine Dauvergne and Jenni Millbank, 'Before the High Court: Applicants S396/2002 and S395/2002, a Gay Refugee Couple from Bangladesh', Sydney Law Review, Vol.25 (2003), p.97 and Jenni Millbank, 'The Role of Rights in Asylum Claims on the Basis of Sexual Orientation', Human Rights Law Review, Vol.4 (2004), p.193.

${ }^{4}$ See, e.g.: in Canada, Re XMU [1995] CRDD No 146 (Quicklaw), IRB Reference T94-06899 (23 January 1995); and in New Zealand, Re GJ [1995] Refugee Appeal 1312/93 (30 August 1995).

5 Appellants S395/2002 and S396/2002 v. Minister for Immigration and Multicultural Affairs (2003) 216 CLR 473 per McHugh and Kirby JJ, para 18. The earlier levels of judicial review are: Kabir v. Minister for Immigration and Multicultural Affairs [2001] FCA 968 (Federal Court, 26 July 2001) and Kabir v. Minister for Immigration and Multicultural Affairs [2002] FCAFC 20 (Full Federal Court, 22 February 2002). The original tribunal level decision is RRT Reference N99/28381 and N99/28382 (Unreported, 5 February 2001), but this is not publicly available.

${ }^{6}$ Appellants S395/2002 and S396/2002 v. Minister for Immigration and Multicultural Affairs (2003) 216 CLR 473. The two majority judgments are by Gummow and Hayne JJ jointly and McHugh and Kirby JJ jointly.

7 The Australian cases were all obtained from the Australasian Legal Information Institute database (http:/ /www.austlii.edu.au), whilst the UK cases were obtained from the Electronic Immigration Network case database (http://www.ein.org.uk), the Asylum and Immigration Tribunal website (http://www.ait.gov.uk), and LEXIS.

${ }^{8}$ The first phase of the study analysed all available Australian and Canadian decisions on sexual orientation and refugee status over the period of 1994-2000: see discussion in Catherine Dauvergne and Jenni Millbank, 'Burdened by Proof: How the Australian Refugee Review Tribunal Has Failed Lesbian and Gay Asylum Seekers', Federal Law Review, Vol.31 (2003), p.299 and Jenni Millbank, 'Imagining Otherness: Refugee Claims on the Basis of Sexuality in Canada and Australia', Melbourne University Law Review, Vol.26 (2002), p.144. In the second phase of the study these decisions were updated to the end of 2007 and the pool was widened to include all available refugee cases on sexual orientation from the UK and New Zealand. 
9 The study counted 'positive' or 'negative' decisions from the perspective of the applicant, even if (as in the case of judicial review and also some UK tribunal outcomes) the decision is one of remittal and reconsideration of the claim rather than an ultimate positive determination of refugee status. This gives an inflated sense of 'positive' outcomes, as we do not have access to the majority of the remittal determinations and some, perhaps many, of these will ultimately be negative to the applicant. However, we include the judicial review decisions for the very reason that they are often the only publicly available record of a case, with the original negative tribunal determination usually not released.

10 The success rate for applicants in Australia in the first phase of the research covering 1994-2000 was 22 per cent at tribunal level (and remains 22 per cent when judicial review decisions are also included) and from 2001-2007 was 37 per cent at tribunal level (or 28 per cent when judicial review decisions are included). Whilst there was a marked increase in the success rates at RRT level, our conclusion that there has not been a sizable increase in the success rate in Australia is based upon the whole pool including judicial review cases, for two reasons. First, there was a sharp reduction in the proportion of released RRT decisions post-2000 and, second, most of the judicial review determinations arose from RRT decisions that were not released; thus we treated the judicial review decisions as proxy for the unreleased RRT decisions in determining an overall success rate. In the UK, the positive decision rate was 50 per cent at tribunal level from 1994-2000 (8 of 16 cases, although note that 4 of these positive decisions led to remittal whilst 4 were actual grants of refugee status). The positive rate falls to 23 per cent when the 19 judicial review decisions are included. The positive decision rate was 37 per cent at tribunal level from 2001-2007 (20 of 54 decisions, although note that 8 of these positives were remittals, whilst 12 were actual grants of refugee status) with the positive rate remaining 37 per cent when judicial review decisions are included.

${ }^{11}$ In Australia the original decision on refugee status is taken by a delegate of the Minister for Immigration and Citizenship (also known variously through the period of this study as the Minister for Immigration and Multicultural Affairs and the Minister for Immigration and Multicultural and Indigenous Affairs) and in the UK by a delegate of the Home Secretary, in both countries a fairly low ranking bureaucratic officer. If this determination is negative, the applicant can apply for a de novo merits review of the decision. In Australia this review is undertaken by the Refugee Review Tribunal (RRT) which sits with a single member. In the UK until April 2005 this review was undertaken by the Immigration Appellate Authority (IAA) in a twotier system; first, an immigration adjudicator reviewed the decision de novo and then leave could be given to the Immigration Appeal Tribunal (IAT) which until 2002 provided a second level of de novo review and after 2002 was limited to points of law by the Nationality, Immigration and Asylum Act 2002 (UK). From 2005 the two-tier structure was abolished and replaced by the Asylum and Immigration Tribunal (AIT): Asylum and Immigration (Treatment of Claimants, etc.) Act 2004 (UK). The AIT can only grant review based on an error of law.

${ }^{12}$ See, e.g., Richard Rawlings, 'Review, Revenge and Retreat', Modern Law Review, Vol.68 (2005), p.378; Catherine Dauvergne, 'Sovereignty, Migration and the Rule of Law in Global Times', Modern Law Review, Vol.67 (2004), p.588.

13 These being the Minister's delegate, the RRT, the Federal Court, the Full Federal Court and the High Court. Note, however, that at the last three levels, the review was limited to points of law; the facts as found by the RRT were assumed.

${ }^{14}$ See NAOX v. Minister for Immigration and Multicultural and Indigenous Affairs [2006] FMCA 434 (13 April 2006) (note that the second RRT decision is not publicly available).

${ }^{15}$ See V95/03527 [1996] RRTA 246 (9 February 1996), p.7 of typescript.

${ }^{16}$ See, e.g., R v. Secretary of State for the Home Department ex parte Binbasi [1989] Imm AR 595, p.5 of typescript; Boyd v. Secretary of State for the Home Department [2000] UKIAT 00TH01419 (1 June 2000), p.2 of typescript.

${ }^{17}$ See, e.g., Jain v. Secretary of State for the Home Department [1999] EWJ No 5243 (6 October 1999), para 9. See also: T v. Special Immigration Adjudicator [2000] EWJ 3020 (11 May 2000); Dumitru v. Secretary of State for the Home Department [2000] UKIAT 00TH00945 (3 April 2000); V99 / 10346 [2001] RRTA 568 (20 June 2001).

${ }^{18}$ See, e.g., V98/08356 [1998] RRTA 4841 (28 October 1998); N01/40155 [2003] RRTA 138 (18 February 2003). In an early UK case this was characterised as 'inviting persecution': R v. Secretary of State for the Home Department ex parte Binbasi [1989] Imm AR 595, p.4 of typescript.

19 See, e.g., V97/06483 [1998] RRTA 27 (5 January 1998); this was also a finding in RRT Reference N97/20994 (Unreported, 4 May 1998) and RRT Reference N98/2231 (Unreported, 22 September 1998) cases that have been removed from the Australasian Legal Information Institute database since the first phase of the study are on file with the author.

${ }^{20}$ See, e.g., N99/29824 [2001] RRTA 890 (16 October 2001).

${ }^{21}$ See, e.g.: V95/02999 [1995] RRTA 897 (26 April 1995); V97/06802 [1997] RRTA 3846 (30 September 1997). 
${ }^{22}$ The Convention definition and grounds are outlined above note 2. See, e.g.: 'Freedom of religion is of course a fundamental human right. Furthermore, the public profession of one's religion will normally be an essential part of the practice of one's religion ... so the inability to publicly profess and practice one's religion is a clear violation of freedom of religion. This is not the case with sexuality. ... Public manifestation of homosexuality is not an essential part of being homosexual.' V98/08356 [1998] RRTA 4841 (28 October 1998), not disturbed on judicial review: LSLS v. Minister for Immigration and Multicultural Affairs [2000] FCA 211 (6 March 2000).

${ }^{23}$ Over the period of 1994-2003 the failure rate of lesbian applicants before the RRT was 86 per cent and the failure rate of gay male applicants before the RRT was 73 per cent.

${ }^{24} 64$ of 65 cases in which discretion was required or expected were negative to the applicant. There were a further 11 judicial review cases where discretion was required or assumed, of which 10 were negative.

25 There were 61 AIT and IAT cases, 21 of which raised discretion. Of those 21, it was apparent from the decision that 19 required or expected discretion. These figures are drawn from 1994 until November 2004 as it took several months for the $S 395$ and $S 396$ decision to become known in the UK.

${ }^{26}$ Discretion was also raised in 37 UK judicial review cases through that period. Of those cases it was clear that discretion was expected or required in 13 cases, 12 of which were negative to the applicant.

27 See, e.g., above note 3, see also Jenni Millbank, “A Preoccupation with Perversion": The British Response to Refugee Claims on the Basis of Sexual Orientation 1989-2003', Social and Legal Studies, Vol.14 (2005), p.115.

${ }^{28}$ This idea is explored in the work of many scholars but see, e.g., Gail Mason, The Spectacle of Violence: Homophobia, Gender, and Knowledge (London: Routledge 2002).

${ }^{29}$ For example, 'The right to free expression of sexuality does not extend so far as a right to publicly proclaim one's sexuality' and it is reasonable to avoid 'overt manifestations of homosexuality such as public embracing' which, whilst 'irksome and unjust', is 'not an infringement of human rights': V96/05496 [1998] RRTA 196 (15 January 1998).

${ }^{30}$ See, e.g., V99/10323 [2000] RRTA 456 (14 April 2000).

${ }^{31}$ See, e.g., EK v. Secretary of State for the Home Department [2004] UKIAT 00021, para 16; 071723892 [2007] RRTA 323 (5 December 2007).

${ }^{32}$ See, e.g., MV v. Secretary of State for the Home Department [2003] UKIAT 00005, para 11.

${ }^{33}$ See for example V97/06483 [1998] RRTA 27 (5 January 1998) where this term is attributed to the claimant.

${ }^{34}$ Nez̧hadian v. Minister for Immigration and Multicultural Affairs [2001] FCA 1415 (18 October 2001), para 12.

${ }^{35}$ WABR v. Minister for Immigration and Multicultural Affairs [2002] FCAFC 124 (10 May 2002), para 23. The Full Court further held that, 'It is not appropriate to submit that the ability to proclaim one's sexual preference is an essential right, the denial of which would or could lead to persecution': ibid., para 19.

${ }^{36}$ See, e.g., Khanmeeri v. Minister for Immigration and Multicultural and Indigenous Affairs [2002] FCA 625 (17 May 2002); LSLS v. Minister for Immigration and Multicultural Affairs [2000] FCA 211 (6 March 2000).

${ }^{37}$ See, e.g.: Guy Goodwin-Gill and Jane McAdam, The Refugee in International Law, 3rd ed. (Oxford: Oxford University Press 2007), p.123, para 5.61; James Hathaway and Michelle Foster, 'Internal Protection/Relocation/Flight Alternative as an Aspect of Refugee Status Determination' in Erika Feller, Volker Türk and Frances Nicholson (eds.), Refugee Protection in International Law: UNHCR's Global Consultations on International Protection (Cambridge: Cambridge University Press 2003), pp.357-417.

${ }^{38}$ See, e.g.: Januzi v. Secretary of State for the Home Department [2006] 2 AC 426 (UK); Minister for Immigration and Multicultural Affairs v. Khawar (2002) 210 CLR 1 (Australia); Ranganathan v. Canada (Minister of Citizenship and Immigration) [2001] 2 FC 164.

${ }^{39}$ See, e.g., N02/41697 [2003] RRTA 457 (22 May 2003). Note that this case also held that the inability to live openly with a partner did not constitute 'serious harm' within the definition of persecution in the relevant Act. See also SZAHV v. Minister for Immigration [2004] FMCA 28 (28 January 2004) where the Magistrate uncritically reproduced the RRT's finding that 'in the larger cities in Ghana, in particular Accra, it seems that there is no real impediment upon homosexuals living an openly gay lifestyle', para 31 (the Magistrate in this case did however find, based on S395 and S396, that the relocation reasoning had been clouded by the assumption of discretion, and remitted the matter for redetermination).

${ }^{40}$ See, e.g., NAIK v. Minister for Immigration and Multicultural and Indigenous Affairs [2003] FMCA 400 (1 September 2003) (referring to 'independent information in relation to gay bars in Nigeria', para 14); N97/18897 [1998] RRTA 4984 (13 November 1998).

${ }^{41}$ See, e.g., JD (Zimbabwe) v. Secretary of State for the Home Department [2004] UKIAT 00259 where a lesbian from Zimbabwe claimed that she could not maintain a 'cloak of invisibility' because she had been exposed and the IAT held that she could internally relocate and act with discretion in order to 'attain invisibility': para 19. In Australia see, e.g.: V99/10323 [2000] RRTA 456 (14 April 2000); N99/29824 [2001] RRTA 890 
(16 October 2001). The assumption of self-concealment continues to be embedded in relocation reasoning in some later decisions: see, e.g., 071263822 [2007] RRTA 115 (13 June 2007).

42 Transcript of an RRT hearing quoted on judicial review upholding the original decision (which also rested on credibility concerns): NADO v. Minister for Immigration and Multicultural and Indigenous Affairs [2003] FCA 215, para 24. A further appeal to the Full Federal Court also failed: $N A D O$ v. Minister for Immigration and Multicultural and Indigenous Affairs [2003] FCAFC 169 (8 August 2003).

${ }^{43}$ For example in RRT Reference N98/23955 (unreported, 24 September 1998) the tribunal held that the applicant should be 'able to conduct himself in a manner acceptable to his own society' at page 8 of typescript. The tribunal goes on to state: 'Many societies, including our own, are homophobic' (ibid.). The decision is from the first phase of the study and is no longer available on the Australasian Legal Information Institute database; on file with author.

44 See, e.g.: N01/36734 [2002] RRTA 898 (8 October 2002); N03/45734 [2003] RRTA 674 (18 July 2003); N02/44482 [2003] RRTA 1076 (10 November 2003).

45 See, e.g., in Australia: SAAM v. Minister for Immigration and Multicultural Affairs [2002] FCA 444 (18 April 2002); Khalili Vabed v. Minister for Immigration and Multicultural Affairs [2001] FCA 1404 (4 October 2001); $S A A F$ v. Minister for Immigration and Multicultural Affairs [2002] FCA 343 (28 February 2002); Nezhadian v. Minister for Immigration and Multicultural Affairs [2001] FCA 1415 (18 October 2001); WABR v. Minister for Immigration and Multicultural Affairs [2002] FCAFC 124 (10 May 2002). This conclusion was held unreviewable as a question of fact in Gholami v. Minister for Immigration and Multicultural Affairs [2001] FCA 1091 (7 August 2001). In the UK see, e.g., Musavi v. Secretary of State for the Home Department [2002] UKIAT 04050 (30 August 2002), although detailed expert evidence admitted in more recent cases has helped to dispel this myth: see, e.g., HS (Iran) v. Secretary of State for the Home Department [2005] UKAIT 00120 (4 August 2005).

${ }^{46}$ See, e.g., in the UK, Jain v. Secretary of State for the Home Department [1999] EWJ No 5243 (6 October 1999) and in Australia, MMM v. Minister for Immigration and Multicultural Affairs (1998) 90 FCR 324; see discussion in Millbank, 'A Preoccupation with Perversion' (note 27).

47 W ABR v. Minister for Immigration and Multicultural Affairs [2002] FCAFC 124 (10 May 2002), para 25. See also YF (Eritrea) v. Secretary of State for the Home Department [2003] UKIAT 00177 (5 December 2003), para 18.3 and Saeed v. Secretary of State for the Home Department [2002] UKIAT 01465 (10 May 2002), para 6, quoting adjudicator.

${ }^{48}$ See T v. Special Immigration Adjudicator [2000] EWJ No 3020 (11 May 2000), para 2.

${ }^{49}$ See Dauvergne and Millbank (note 3).

50 Appellants S395/2002 and S396/2002 v. Minister for Immigration and Multicultural Affairs (2003) 216 CLR 473 per McHugh and Kirby JJ, para 35, and per Gummow and Hayne JJ, paras 80-82.

${ }^{51}$ See, e.g., SZDLD v. Minister for Immigration and Multicultural and Indigenous Affairs [2005] FMCA 113 (18 February 2005). Of the 102 Australian judicial review cases in this period, 16 specifically reference $S 395$ and S396.

52 In addition, of the 21 judicial review cases during this period that raised discretion, 5 were successful.

${ }^{53}$ N04/48689 [2004] RRTA 679 (22 October 2004), p.10 of typescript. Concealment is framed as a 'double life' rather than a 'normal life' in N05/50670 [2005] RRTA 88 (19 May 2005) and in 071818233 [2008] RRTA 62 (15 February 2008) it is described as a 'façade'. See also 071411578 [2007] RRTA 172 (9 August 2007) for the influence of $S 395$ and $S 396$.

${ }^{54}$ For example, 'even if he was able to hide his homosexuality to reduce the risk of harm, the Tribunal finds that having to do so would be persecutory in itself given the freedom he has experienced here': N04/49627 [2005] RRTA 7 (25 February 2005), p.31 of typescript. See also: N05/51364 [2005] RRTA 137 (29 July 2005); V05/18306 [2006] RRTA 67 (22 May 2006); 071676868 [2007] RRTA 260 (17 October 2007); 071818233 [2008] RRTA 62 (15 February 2008).

55 Prior to 2005 there were two levels of tribunal review in the UK. Until 2002 both levels, the adjudicator and the IAT, exercised merits review; from 2002 to 2005, only the adjudicator exercised merits review. See AIT Review Report, April 2006, http://www.ait.gov.uk/Documents/AboutUs/AITReviewReport.pdf (visited 2 May 2008); Asylum and Immigration (Treatment of Claimants, etc.) Act 2004 (UK).

${ }^{56}$ Similarly, of the 12 judicial review cases available for this period, 7 raised discretion and only 3 of those 7 were negative decisions.

57 Appellants S395/2002 and S396/2002 v. Minister for Immigration and Multicultural Affairs (2003) 216 CLR 473, para 43 (emphasis in original).

58 Ibid., para 43. Gummow and Hayne JJ also found the tribunal in error because it 'did not ask why the appellants would live "discreetly": para 88 (emphasis in original).

59 Ibid. Callinan and Heydon JJ stated at para 108: 'it is clear the appellants did not seek to make a case that they wished to express their homosexuality in other than a discreet, indeed personal way. There may be 
good reason, divorced entirely from fear, for this.' They continue: '... in many societies, both heterosexual and homosexual couples regard their domestic and sexual arrangements and activities as entirely private'.

${ }^{60}$ This was adopted for example in $R G$ where the adjudicator and Court of Appeal on review held that the applicant had to demonstrate that external threat 'was the reason that the pattern of behaviour forced on him was different from that which otherwise he would have adopted': RG (Colombia) v. Secretary of State for the Home Department [2006] EWCA 2528 (20 January 2006), para 12 (emphasis added).

${ }^{61}$ Appellants S395/2002 and S396/2002 v. Minister for Immigration and Multicultural Affairs (2003) 216 CLR 473, para 92 (emphasis added). This approach is approved in the IAT decision MN (Kenya) v. Secretary of State for the Home Department [2005] UKIAT 0021 (28 January 2005), para 10.

62 Appellants S395/2002 and S396/2002 v. Minister for Immigration and Multicultural Affairs (2003) 216 CLR 473, para 106.

${ }^{63}$ Ibid., para 110.

${ }^{64}$ IAT findings of 20 December 2004, quoted on review in Amare v. Secretary of State for the Home Department [2005] EWCA Civ 1600 (20 December 2005), para 6.

65 N99/28400 [2001] RRTA 846 (26 September 2001), upheld on review in SZAOD v. Minister for Immigration and Multicultural and Indigenous Affairs [2004] FMCA 89 (19 March 2004) where it was described as 'rather deftly' avoiding error identified in $S 395$ and $S 396$.

${ }^{66}$ AT (Iran) v. Secretary of State for the Home Department [2005] UKAIT 00119 (27 July 2005), para 28. The sentence concludes: 'and still more so of a number of races considered "uncivilised" so far as they still exist.'

${ }^{67}$ See, e.g., the following recent Australian cases holding that the applicant is 'naturally' discreet: $S Z A N S \mathrm{v}$. Minister for Immigration and Multicultural and Indigenous Affairs [2005] FCAFC 41 (17 March 2005), para 18, quoting the tribunal (RRT decision of 29 August 2002, not publicly available); SZATS v. Minister for Immigration and Multicultural and Indigenous Affairs [2004] FMCA 660 (11 November 2004), para 21, quoting the tribunal (RRT decision of 29 September 2000, not publicly available, upheld on review); N00/34199 [2002] RRTA 543 (19 June 2002), pp. 7 and 11 of typescript, upheld on review in SZBSA v. Minister for Immigration and Multicultural and Indigenous Affairs [2005] FMCA 1248 (31 August 2005), para 6 (quoting RRT with approval). In the UK see: Z v. Secretary of State for the Home Department [2004] EWCA Civ 1578 (2 December 2004), para 17; Amare v. Secretary of State for the Home Department [2005] EWCA Civ 1600 (20 December 2005), para 4, quoting IAT findings; EK (Uganda) v. Secretary of State for the Home Department [2004] UKIAT 00021, para 16. At times the arguments of the relevant government have betrayed the knowledge that this 'free' choice is not so free, yet still presented as a natural one, for example in 2006 the Home Secretary argued that, 'because in Algeria there are no gay rights, there are no opportunities for displaying homosexuality ... and it will be impossible for him not to be discreet: B v. Secretary of State for the Home Department [2007] EWHC 2528, para 20 (emphasis added, although note that the court did in fact remit for redetermination in that case). There are also some rare examples in Canadian law: see, e.g., Hussain v. Canada (Minister of Citizenship and Immigration) [2004] RPDD No 732 (19 March 2004).

${ }^{68}$ Including when the first instance determination was in fact prior to the $S 395$ and $S 396$ decision: see, e.g., S135 of 2003 v. Minister for Immigration and Multicultural and Indigenous Affairs [2004] FCA 1521 (16 July 2004).

${ }^{69}$ See, e.g., Z v. Secretary of State for the Home Department [2004] EWCA Civ 1578 (2 December 2004), para 20; MN (Kenya) v. Secretary of State for the Home Department [2005] UKIAT 0021 (28 January 2005), para 27; XY v. Secretary of State for the Home Department [2008] EWCA Civ 911 (31 July 2008), para 14; HJ v. Secretary of State for the Home Department [2008] UKAIT 00044 (18 April 2008), paras 41-42, 45. Some Australian cases have implicitly taken the same view, see: SZBSA v. Minister for Immigration [2005] FMCA 1248 (31 August 2005).

${ }^{70}$ Quoted on review, RG (Colombia) v. Secretary of State for the Home Department [2006] EWCA 2528 (20 January 2006), para 17.

${ }_{71}$ Quoted on review, RG (Colombia) v. Secretary of State for the Home Department [2006] EWCA 2528 (20 January 2006), para 6.

${ }^{72}$ Quoted on review, RG (Colombia) v. Secretary of State for the Home Department [2006] EWCA 2528 (20 January 2006), para 7.

${ }^{73}$ RG (Colombia) v. Secretary of State for the Home Department [2006] EWCA 2528 (20 January 2006), para 18. ${ }^{74}$ Abmed v. Secretary of State for the Home Department [2000] INLR 1.

75 'Although $S 395$ was presented to the court that granted permission in this appeal as a new departure in refugee law, and for that reason justifying the attention of this court, in truth it is no such thing': $Z$ v. Secretary of State for the Home Department [2004] EWCA Civ 1578 (2 December 2004), para 16 and quoted in DW (Jamaica) v. Secretary of State for the Home Department [2005] UKIAT 00168 (28 November 2005), para 78. See also J v. Secretary of State for the Home Department [2006] EWCA Civ 1238 (26 July 2006), para 10. In Amare v. Secretary of State for the Home Department [2005] EWCA Civ 1600 (20 December 2005), the court appears to prefer the early English case of Jain v. Secretary of State for the Home Department [1999] EWJ No 
5243 (6 October 1999). In addition, in LK (Zimbabwe) v. Secretary of State for the Home Department [2005] UKAIT 00159 (17 November 2005), the Home Secretary unsuccessfully argued on review that the adjudicator had committed a legal error by applying S395 and S396 instead of inconsistent English tribunal level authority.

${ }^{76}$ HYSI v. Secretary of State for the Home Department [2005] EWCA Civ 711 (15 June 2005).

77 HYSI v. Secretary of State for the Home Department [2005] EWCA Civ 711 (15 June 2005), paras 33-34.

${ }^{78}$ AT (Iran) v. Secretary of State for the Home Department [2005] UKAIT 00119 (27 July 2005), para 28.

${ }^{79}$ JM v. Secretary of State for the Home Department [2008] UKIAT 00065 (11 June 2008), para 149. Note also the Secretary of State's argument that 'even if some modification of conduct was required out of respect for social norms' this was not persecution: at para 77 (emphasis added).

${ }^{80}$ HJ v. Secretary of State for the Home Department [2008] UKAIT 00044 (18 April 2008), para 10. The case of HJ was a reheard determination following a successful claim for judicial review by the applicant in $J \mathrm{v}$. Secretary of State for the Home Department [2006] EWCA Civ 1238 (26 July 2006). In J the Court of Appeal had endorsed the approach of $S 395$ and $S 396$.

${ }^{81}$ HJ v. Secretary of State for the Home Department [2008] UKAIT 00044 (18 April 2008), para 45.

${ }^{82}$ HJ v. Secretary of State for the Home Department [2008] UKAIT 00044 (18 April 2008), para 46.

83 The claimant has been granted leave by the Court of Appeal to apply for judicial review of the decision in HJ: E-mail communication with S. Chelvan, 3 October 2008.

${ }^{84}$ Krasniqi v. Secretary of State for the Home Department [2001] UKIAT 01TH02140 (19 June 2001), para 2.

${ }^{85} Z$ v. Secretary of State for the Home Department [2001] UKIAT 01TH02634 (8 November 2001), para 4.

${ }^{86}$ In fact there were markedly fewer tribunal cases on sexual orientation available in Australia in the years 2005, 2006, and 2007 (down to 12, 9, and 20, compared to an average of around 30 tribunal decisions per year in preceding years) which could be the result of any or all of the following: a smaller number of actual claims, a higher success rate before the Minister's delegate (thus leading to fewer applications for review before the tribunal), or the tribunal selecting fewer cases for release. The Minister does not keep figures on the number or success rates of claims according to ground of claim so we are unable to assess the first two possibilities. However it is clear from the RRT Annual Reports that in the years 2006-2007 and 2004-2005 the tribunal released only 8 per cent and 10 per cent of decisions from those years, respectively, rather than its stated target of 20 per cent of decisions: see Migration Review Tribunal \& Refugee Review Tribunal Annual Report 2006-2007 (2007), p.18; Migration Review Tribunal \& Refugee Review Tribunal Annual Report 2004-2005 (2005), p.9. No information is available from the 2005-2006 annual report. This leads us to infer that the drop in the number of decisions is more likely to be a result of this overall release policy rather than reflecting either fewer claims or a higher earlier success rates.

8757 of 351 decisions prior to December 2003 disclosed significant doubts of the claimants' membership of the particular social group, whilst 67 of 176 cases did so afterwards.

${ }^{88}$ The tribunal decision is not publicly available, but its reasoning can be discerned from the application for judicial review arising from it: NAOX v. Minister for Immigration and Multicultural Affairs [2006] FMCA 434 (13 April 2006). Despite the unsuccessful attempt of the applicants to argue both bias and issue estoppel in that case, the Minister subsequently consented to remittal, and the claim was heard for a third time by the RRT in 2008, again resulting in a negative decision that is not publicly available: E-mail communication with Tina Edwards, RRT, 22 October 2008.

${ }^{89}$ In the only successful judicial review case concerning discretion prior to $S 395$ and $S 396, W 133 / 01 A \mathrm{v}$. Minister for Immigration and Multicultural Affairs [2002] FCA 395 (5 April 2002), the Federal Court found an error of law in the tribunal's ruling that discretion was possible because this was inconsistent with another finding that past acts of persecution based on sexual orientation had occurred: N01/37352 [2001] RRTA 381 (24 April 2001). When the case was remitted to a differently constituted RRT, it held that the man was not gay after all. That decision (which is not publicly available) was then held to be unreviewable as it was a determination of fact: WAIH v. Minister for Immigration and Multicultural and Indigenous Affairs [2003] FMCA 40 (4 March 2003), para 23.

${ }^{90}$ See, e.g.: 'This is a claim which is easily made but not easily tested', N04/48510 [2004] RRTA 367 (17 May 2004), p.11 of typescript; 'The claim of being homosexual is in many ways an easy one to make, and a difficult one to dispute', N97/16114 [1998] RRTA 4882 (2 November 1998), p.13 of typescript; SZIGI v. Minister for Immigration and Multicultural Affairs [2006] FMCA 1800 (20 November 2006), para 25, quoting the tribunal (8 December 2005, decision not publicly available).

${ }^{91}$ See, e.g.: 'I must warn you to be especially careful in considering the evidence in a case where sexual allegations are made. ... It is a very easy allegation to make. It is often very hard to contradict. ... It is hard to contradict, and of course, it can be of a very serious and distressing nature': R v. Johns (unreported, SA SC, 26 August 1992); this warning was ultimately held to be an error of law on appeal, Question of Law Reserved on Acquittal Pursuant to Section 350(1 A) Criminal Law Consolidation Act (No 1 of 1993) Judgment No 3896 (1993) 59 SASR 214. 
92 One case noted a somewhat improbable incident in which six members of a male sporting team that had visited Australia all claimed refugee status on the basis of their homosexuality: 071626698 [2008] RRTA 5 (4 January 2008).

93071397909 [2007] RRTA 187 (15 August 2007). The questioning in this case also appeared sensitive, with the decision-maker noting that ' $[\mathrm{w}]$ ith these issues in mind, the Tribunal explored with the applicant a wide range of circumstances relevant to its assessment. These included his self-identity; his self-disclosure and others' perceptions of him; his past experiences; his knowledge of and association with other homosexuals; his relationships and personal contacts; and incidental evidence': at page 9 of typescript. However even with careful questioning that is sensitive to such issues, the difficulties introduced by translation may still render the inquiry incomprehensible: see, e.g., transcript quoted in SZIGI v. Minister for Immigration and Multicultural Affairs [2006] FMCA 1800 (20 November 2006), paras 10-14.

94 Nicole LaViolette, 'Coming Out to Canada: The Immigration of Same-Sex Couples under the Immigration and Refugee Protection Act', McGill Law Journal, Vol.49 (2004), p.969, at p.996.

95 See, e.g.: N04/48953 [2005] RRTA 363 (25 January 2005); N05/50659 [2005] RRTA 207 (17 May 2005); N03/45493 [2003] RRTA 303 (2 April 2003); SZIXG v. Minister for Immigration and Multicultural Affairs [2007] FMCA 1331 (30 July 2007) (RRT decision unavailable); SZKLN v. Minister for Immigration and Citizenship [2007] FMCA 1407 (8 August 2007) (RRT decision unavailable); 071494945 [2007] RRTA 276 (19 September 2007). Conversely when an applicant could establish his familiarity with gay venues in Canberra, the tribunal held that this did not establish that he was gay (although in the same case a lack of familiarity with a local church was held to undermine his claim to be a Christian): SZJSL v. Minister for Immigration and Multicultural Affairs [2007] FMCA 313 (19 February 2007) (RRT decision unavailable).

${ }^{96}$ See, e.g.: SZEOP v. Minister for Immigration and Multicultural Affairs [2006] FMCA 1707 (7 December 2006), para 13; N97/16114 [1998] RRTA 4882 (2 November 1998), pp.6 and 7 of typescript.

97 N05/50659 [2005] RRTA 207 (17 May 2005), p.11 of typescript.

${ }^{98}$ On review the applicant's counsel pointed to a series of passages from the transcript which indicated that this questioning occurred: SZGNJ v. Minister for Immigration and Multicultural and Indigenous Affairs [2006] FMCA 91 (24 February 2006), para 3.

${ }^{99}$ N05/50659 [2005] RRTA 207 (17 May 2005), p.11 of typescript.

100 SZGNJ v. Minister for Immigration and Multicultural and Indigenous Affairs [2006] FMCA 91 (24 February 2006), para 80. This was in part because the findings on credibility were characterised as findings of fact, but also because the ground of claim was that of apprehended bias, which requires a very high threshold to satisfy.

101 See, e.g., SZJSL v. Minister for Immigration and Multicultural Affairs [2007] FMCA 313 (19 February 2007) where the applicant's lack of knowledge that his church condemned homosexuality was held to impugn his claim to being a Christian: RRT quoted at para 8 of FMCA decision. See, also, $S Z A K D$ v. Minister for Immigration and Multicultural and Indigenous Affairs [2004] FMCA 78 (19 March 2004).

102 Quoted on review in SZAKD v. Minister for Immigration and Multicultural and Indigenous Affairs [2004] FMCA 78 (19 March 2004), para 7.

103 SZAKD v. Minister for Immigration and Multicultural and Indigenous Affairs [2004] FMCA 78 (19 March 2004), para 26. The second RRT decision, which is not publicly available, was again negative to the applicant: E-mail communication with Ailsa Wilson, RRT, 24 April 2008.

104 See, e.g.: 071494945 [2007] RRTA 276 (19 September 2007); SZEND v. Minister for Immigration and Citizenship [2007] FMCA 1171 (21 June 2007) (RRT decision not publicly available).

105 See SZBFO v. Minister for Immigration and Multicultural and Indigenous Affairs [2005] FMCA 207 (2 March 2005), where failure to recognise the word 'kothi' led the tribunal to reject the applicant's claim to be gay; upheld on review a second time in SZGQG v. Minister for Immigration and Multicultural and Indigenous Affairs [2006] FMCA 193 (14 February 2006). Kothi is a very class-specific word used by effeminate gay men: see Peoples' Union for Civil Liberties, Karnataka, Human Rights Violations against the Transgender Community: A Study of Kothi and Hijra Sex Workers in Bangalore, India (September 2003), p.19.

106 SZKIS v. Minister for Immigration and Citizenship [2007] FMCA 1223 (18 July 2007), para 31, citing RRT decision of 13 February 2007 (not publicly available). Another common thread was that decision-makers took evidence that the applicant had been married or in an opposite-sex relationship as evidence that they were lying as it was 'inconsistent' with being gay, rather than as evidence that they were bisexual or had accepted their homosexuality later in life (see, e.g., 071204626 [2007] RRTA 146 (13 August 2007); N05/51729 [2005] RRTA 311 (8 November 2005); N02/42894 [2006] RRTA 1093 (14 November 2003)) though this did not always occur (see, e.g., N05/50670 [2005] RRTA 88 (19 May 2005)).

${ }^{107}$ For example, '[t] he Applicant's evidence also lacks important detail, for example about the nature and type of sexual activity on the video, who was involved in specific activities': N97/15882 [1997] RRTA 3396 (5 September 1997), p.7 of typescript; judicial review denied subsequently in SZEOE v. Minister for Immigration and Multicultural Affairs [2004] FMCA 1096 (16 December 2004) and SZEOE v. Minister for 
Immigration and Multicultural Affairs [2005] FCA 694 (31 May 2005). In NAIK v. Minister for Immigration and Multicultural and Indigenous Affairs [2003] FMCA 400 (1 September 2003), the applicant was disbelieved because he was 'halting and evasive' when questioned about 'critical issues' in his testimony which appear to centre upon being discovered engaged in gay sex (RRT decision not publicly available). See also 071913999 [2008] RRTA 35 (18 February 2008) in which the tribunal member asked the applicant in the course of the hearing to supply his login name and password to the online social networking and dating websites he had joined.

108 Quoted on review in WAAG v. Minister for Immigration and Multicultural and Indigenous Affairs [2002] FMCA 191 (30 August 2002), para 12 (RRT decision not publicly available).

${ }_{109}$ Quoted on review in WAAG v. Minister for Immigration and Multicultural and Indigenous Affairs [2002] FMCA 191 (30 August 2002), para 10 (RRT decision not publicly available).

110 This was quoted by both Heydon $\mathrm{J}$ and Gummow $\mathrm{J}$ in the leave to appeal transcript: $W A A G \mathrm{v}$. Minister for Immigration and Multicultural and Indigenous Affairs [2004] HCA Trans 475, p.6 of typescript.

111 WAAG v. Minister for Immigration and Multicultural and Indigenous Affairs [2002] FMCA 191 (30 August 2002), para 23.

112 SBAN v. Minister for Immigration and Multicultural and Indigenous Affairs [2002] FCAFC 431 (18 December 2002), para 65.

113 Ibid.

$114 W A A G$ v. Minister for Immigration and Multicultural and Indigenous Affairs [2004] HCATrans 475 per Gummow J, p.4 of typescript. Gummow J also noted with characteristic attention to detail that 'They do not look upon Alexander the Great as much of a hero in Iran, I would have thought': p.10 of typescript.

115 Ibid., pp. 3 and 6 of typescript.

116 Ibid., pp. 10 and 11 of typescript, respectively.

117 Ibid., p. 9 of typescript.

118 Ibid., p.5 of typescript.

${ }^{119}$ See $W A A G$ v. Minister for Immigration and Multicultural and Indigenous Affairs [2005] HCA Trans 655.

120 'This court has been criticised before for making comments upon the apparent illogicality of findings by the Tribunal on the question of homosexuality and for that reason will not risk further reprimand': SZAKE v. Minister for Immigration and Multicultural and Indigenous Affairs [2004] FMCA 138 (4 March 2003), para 8 (note that this was the same Magistrate whose decision was overturned by the Full Federal Court in $W A A G)$.

121 On remittal the applicant was ultimately successful in his claim. The re-heard determination, N05/52122 (17 November 2005), is not publicly available but was accessed by the author through a Freedom of Information Request.

122 See, e.g., Deborah Anker, 'Determining Asylum Claims in the United States: A Case Study on the Implementation of Legal Norms in an Unstructured Adjudicatory Environment' Review of Law and Social Change, Vol.19 (1992), p.433; Michael Kagan, 'Is Truth in the Eye of the Beholder? Objective Credibility Assessment in Refugee Status Determination', Georgetown Immigration Law Journal, Vol.17 (2003), p.367; Gregor Noll (ed.), Proof, Evidentiary Assessment and Credibility in Asylum Proceedings (Leiden: Martinus Nijhoff 2005).

123 See, e.g., Brian Gorlick, 'Improving Decision-Making in Asylum Determinations', UNHRC Working Paper No 119 (2005). Canada has had detailed policy guidelines on credibility assessment for some time, whilst Australia and the UK have recently introduced brief guidelines: see Refugee Protection Division (Canada), Assessment of Credibility in Claims for Refugee Protection (current version 2004); Migration Review Tribunal and Refugee Review Tribunal (Australia), Guidance on the Assessment of Credibility (2006, updated 2008); Home Office (UK), Asylum Instructions on Assessing Credibility in Asylum and Human Rights Claims (c2007). For critique of the increasingly structured approach to negative credibility assessment in legislation, see: Robert Thomas, 'Assessing the Credibility of Asylum Claims: EU and UK Approaches Examined', European Journal of Migration and Law, Vol.8 (2006), p.79.

${ }^{124}$ François Crépeau and Delphine Nakache, 'Critical Spaces in the Canadian Refugee Determination System: 1989-2002' International Journal of Refugee Law, Vol.20 (2008), p.50. See also Audrey Macklin who argues for critical self-awareness and self-interrogation, 'Truth and Consequences: Credibility Determination in the Refugee Context', International Association of Refugee Law Judges, 1998).

125 Personal communication with Nicole LaViolette.

126 Ibid. See also Nicole LaViolette, 'Gender-Related Refugee Claims: Expanding the Scope of the Canadian Guidelines', International Journal of Refugee Law, Vol. 19 (2007), p.169 at footnote 173.

127 See Immigration and Refugee Board, Compendium of Decisions, Guideline 4, Women Refugee Claimants Fearing Gender-Related Persecution, February 2003 update. Although, LaViolette argues that the gender guidelines have been inadequately utilised to date for lesbian and gay claims and recommends that they be revised to more directly address sexual minorities: see 'Gender-Related Refugee Claims' (ibid.). 
${ }^{128}$ Nicole LaViolette, 'Sexual Orientation and the Refugee Determination Process: Questioning a Claimant About Their Membership in the Particular Social Group', prepared for the Immigration and Refugee Board (2004), p.5.

129 See, e.g., N01/37891 [2001] RRTA 889 (16 October 2001), where the tribunal disbelieved that the applicant was gay, partly on the basis that he 'only ever referred to his claimed sexuality as a sexual or psychological problem. He showed no sign in his evidence of ever having seen his sexuality as a matter of private right': p. 1 of typescript.

130 More commonly a refugee applicant will be asked questions concerning sexual acts when their claim of persecution under any ground involves sexual assault. Whilst not suggesting that such questioning is always undertaken well, it is one which is addressed by gender guidelines in most jurisdictions.

131 See, e.g., N01/37352 [2001] RRTA 381 (24 April 2001) where the Iranian applicant had not disclosed his homosexuality in the first interview because the interpreter was 'an Afghan lady': p.4 of typescript. See, also, N01/37891 [2001] RRTA 889 (16 October 2001) where an Iranian applicant said 'he had been too "shy" to talk about sexuality with the women present at the entry interview': p.9 of typescript. In 2008 the Australian tribunal amended its credibility guidelines to include sexual orientation as a reason to consider 'whether it would be appropriate for an interpreter of a particular gender to assist with the hearing': Migration Review Tribunal and Refugee Review Tribunal (Australia), Guidance on the Assessment of Credibility (2006, updated 2008) para 4.5.

132 See 'Tribunal Promise' Sydney Star Observer, 28 February 2008.

133 Caro Meldrum, 'Refugee Review Tribunal to Develop Sexuality Training', ABC News Online, 15 June 2007, http://www.abc.net.au/news/newsitems/200706/s1952753.htm (visited 23 April 2008).

134 Quoted on review in SZJSL v. Minister for Immigration [2007] FMCA 313 (19 February 2007), para 8 (the tribunal decision in the matter is not publicly available, but is on file with the author). Judicial review was denied but the case is currently under review by the Minister as part of a review of all long-term immigration detainees following a change of government at federal level.

135 See, e.g., Eric Jensen, 'Bisexuality a Result of Detention, Detainee Told', Sydney Morning Herald, 9 May 2007; Harley Dennett, 'Queer Refugee Fears Own Family', Sydney Star Observer, 10 May 2007; see also Meldrum (note 127).

136 Such guidelines were recommended by Amnesty International in 2001: Crimes of Hate, Conspiracy of Silence: Torture and Ill-Treatment Based on Sexual Identity (2001), Recommendation 7. See also Dauvergne and Millbank, 'Burdened by Proof' (note 8).

137 See Department of Immigration and Multicultural Affairs, Guidelines on Gender Issues for Decision Makers, July 1996, published in International Journal of Refugee Law (Special Issue), Vol.9 (1997), p.195.

138 See Immigration Appellate Authority, Asylum Gender Guidelines (2000). These guidelines operated at tribunal level.

139 Asylum Aid, 'Submission of Evidence to the Independent Asylum Commission', 27 July 2007, para 40.

140 See Home Office, Asylum Policy Instructions, 'Gender Issues in Asylum Claims' (2006). These guidelines operate at the level of border control and decisions taken by the Minister's delegate.

141 The Australian guidelines were originally directed to the Minister's delegate rather than to the tribunal but note that omitting to consider the guidelines at tribunal level was held to constitute legal error in Applicants M16 of 2004 v. Minister for Immigration and Multicultural and Indigenous Affairs [2005] FCA 1641 (24 November 2005). This approach was affirmed in a case concerning a lesbian from Uganda in the Federal Magistrates Court in MZXFJ v. Minister for Immigration and Multicultural Affairs [2006] FMCA 1465 (10 October 2006), the only case in our pool to refer to the guidelines. On the Australian guidelines more broadly, see Susan Kneebone, 'Women within the Refugee Construct: "Exclusionary Inclusion”' in Policy and Practice - The Australian Experience', International Journal of Refugee Law, Vol.17 (2005), p.7. On the operation of the UK guidelines generally, see Sophia Ceneda and Clare Palmer, "Lip Service" or Implementation: The Home Office Gender Guidance and Women's Asylum Claims in the UK, Asylum Aid Report (2006).

142 Of the 342 RRT decision in our study decided after the introduction of the gender guidelines in July 1996, including 91 decisions on lesbian claimants, not one referred to the guidelines (although one judicial review case in 2006 did do so, ibid.). In the UK none of the 80 tribunal or judicial review cases in our study decided after the introduction of the gender guidelines in November 2000, including 16 decisions on lesbian claimants, referred to the gender guidelines.

143 Community groups in the UK are currently developing their own sexuality documents in an attempt to 'reduce homophobia and ignorance surrounding LGBT individuals seeking asylum': see UK Lesbian and Gay Immigration Group, 'Sexual and Gender Identity Guidelines Initiative', http://www.uklgig.org.uk/guidelines.htm (visited 1 July 2008). In Australia see Ghassan Kassisieh for the NSW Gay and Lesbian Rights Lobby, From Lives of Fear to Lives of Freedom (2008).

${ }^{144}$ UNHCR, Guidance Note on Refugee Claims Relating to Sexual Orientation and Gender Identity (2008). 
145 See, e.g., Karner v. Austria [2003] ECHR 395 (24 October 2003); EB v. France [2008] ECHR 55 (22 January 2008). 